Poznańskie Studia Teologiczne 28(2014), s. 147-154. doi: $10.14746 /$ pst.2014.28.9

Jacek Salij

Uniwersytet Kardynała Stefana Wyszyńskiego w Warszawie

\title{
Pytanie o ,światło wiary" w perspektywie myśli Tomasza z Akwinu
}

Pojęcie „światło wiary” ma bogatą historię, której warto przypatrzeć się bliżej, zwłaszcza że znalazło się ono w samym nawet tytule encykliki papieża Franciszka Lumen fidei. Otóż do głębszego zrozumienia, czym jest światło wiary, na pewno przyczyni się zobaczenie tego pojęcia w kontekście pojęć strukturalnie pokrewnych.

W ślad za św. Tomaszem z Akwinu pragnę tu rozróżnić cztery radykalnie odmienne pojęcia światła. Od razu jednak zaznaczę, że nie mam zamiaru przedstawiać poglądów ani analiz Akwinaty na ten temat. Jego ujęciami się inspiruję, ale nie zamierzam ich tu rekonstruować.

Podstawą trzech przenośnych pojęć światła jest w dziełach Akwinaty światło materialne, czyli światło w sensie dosłownym. Tomasz nazywa je lux sensibilis $^{1}$ albo lumen materiale ${ }^{2}$. Warto być ostrożnym i nie odnosić do światła materialnego Tomaszowego terminu lumen naturale, gdyż prawie zawsze Tomasz nazywa tak naturalne światło rozumu.

Na lekcjach fizyki uczono nas, że światłem materialnym jest ta część fal elektromagnetycznych, która jest rozpoznawalna dla siatkówki naszego oka. Wobec tego należy rozróżnić ciemność obiektywną i subiektywną. Ciemność obiektywna jest skutkiem braku wspomnianych fal, natomiast ciemność subiektywna jest skutkiem braku oka z odpowiednio wyposażoną siatkówką. Rozróżnienia te nieraz są wykorzystywane $\mathrm{w}$ analizie pojęć przenośnych światła - wystarczy choćby zwrócić uwagę na to, jak często sięgamy po pojęcie zaślepienia ${ }^{3}$.

Trzy przenośne znaczenia światła to:

1. Światło rozumu. Elektroniczny indeks do dzieł św. Tomasza wykazuje 114 użyć pojęcia lumen intellectus (a sprawdzałem jedynie użycia w mianowniku), 34 użycia pojęcia lumen rationis oraz trzy użycia pojęcia lumen synderesis (światło sumienia - skorzystam z okazji, żeby zwrócić uwagę

\footnotetext{
${ }^{1}$ Sancti Thomae de Aquino, 1 Sent. d.3 q.1 a.2 arg.2.

${ }^{2}$ Sancti Thomae de Aquino, 4 Sent. d. 17 q.1 a.2 q-la 1 sc.

${ }^{3}$ Por. np. Sancti Thomae de Aquino, STh 2-2 q.15 a.1.
} 
na niezwykle głębokie określenie sumienia w Syr 17,8, że jest to „oko Boże w naszym sercu").

2. Światło wiary. Pojęcia lumen fidei Tomasz używa 32 razy, częściej jednak - 48 razy - używa pojęcia ,światło łaski”, lumen gratiae. Światło łaski jest to u Tomasza światło wiary ukształtowanej przez miłość (fides caritate formata), czyli wiary, jaką jesteśmy obdarzeni w stanie łaski uświęcającej.

3. Światło chwały. Pojęcia lumen gloriae używa Akwinata 48 razy. Światło chwały jest to uzdolnienie, jakiego żadne stworzenie nie ma ze swojej natury, do oglądania Boga najdosłowniej bezpośrednio, bez pośrednictwa jakiegokolwiek obrazu - a zatem do oglądania Boga z taką bezpośredniością jaka w obecnym porządku poznawania nie jest nam dostępna nawet przy poznawaniu stworzeń od nas niższych. Światło chwały - powiada św. Tomasz - czyni intelekt stworzenia poniekąd bogokształtnym: Lumen gloriae intellectum in quadam deiformitate constituit ${ }^{4}$.

\section{Światło rozumu, czyli zdolność poznawania prawdy i dobra}

Zacznę od podzielenia się moimi własnymi wspomnieniami, kiedy to poniekąd empirycznie przekonałem się, że nawet te zwierzęta, które najwięcej są przez nas podziwiane za zdolności poznawania świata, w którym żyją, pozbawione są światła rozumu. Jakieś ćwierć wieku temu przez całe tygodnie na niebie widać było kometę Haleya. Moja znajoma postanowiła faktem tym zainteresować psa, z którym była aż tak związana, że uważała go wręcz za swojego przyjaciela. $\mathrm{W}$ gwiezdne wieczory wiele razy wychodziła $\mathrm{z}$ nim na spacer, żeby zwrócić mu uwagę na to niezwykłe zjawisko. „Naprawdę wysilałam się - opowiadała mi później - i w żaden sposób nie mogłam doprowadzić do tego, żeby mój przyjaciel zaczął zauważać pojawienie się jaśniejącej na niebie komety Haleya. Po prostu jego zainteresowania poznawcze były zamknięte w horyzoncie potrzeb życiowych oraz ewentualnych zagrożeń”.

Prawdę wychodzącą poza ten horyzont my, ludzie, poznajemy dzięki światłu rozumu. Również dopiero dzięki temu światłu potrafimy rozróżnić dobro i zło. Kiedy w moim klasztorze mieszkały jeszcze siostry, trzymały u siebie kotkę z małym kociakiem. Kiedy jej potomek wydoroślał, uznał klasztor za swoje terytorium i przepędzał własną matkę tak skutecznie, że ta kompletnie zdziczała. Natura nie dała mu ani pamięci, że to jest jego matka, ani zrozumienia, że matce należałaby się z jego strony jakaś wdzięczność.

Jednak przejdźmy do teologii. Otóż pozwolę sobie przypomnieć, że termin „naturalne światło rozumu” znalazł się nawet w jednym z orzeczeń dogmatycznych

\footnotetext{
${ }^{4}$ Sancti Thomae de Aquino, STh 1 q.12 a.6.
} 
Kościoła. Mianowicie w roku 1870 Sobór Watykański I przypomniał, że dzięki naturalnemu światłu rozumu nawet Boga możemy nieco poznać: „Bóg, początek i cel wszystkich rzeczy, może być za pomocą naturalnego światła rozumu (naturali humanae rationis lumine) poznany z pewnością z rzeczy stworzonych"5.

Soborowa konstytucja, w której ten dogmat się znajduje, zarazem zwraca uwagę na to, że światło rozumu może być zmącone i przyćmione naszym moralnym nieuporzą̧dkowaniem, toteż dopiero dzięki Bożemu objawieniu możemy poznać Boga wszyscy, od razu, z całą pewnością i bez domieszki błędu'. O tym, że „przez nieprawość [można] nakładać prawdzie pęta” i ,prawdę Bożą przemienić w kłamstwo", pisał już apostoł Paweł w Rz 1.

Można by sporządzić opasłą antologię spostrzeżeń i pouczeń nauczycieli Kościoła na temat negatywnego wpływu grzechu na światło rozumu. Teraz przypomnę tylko dwie mądre wypowiedzi na ten temat. W roku ok. 180 św. Teofil z Antiochii pisał w Liście do Autolyka:

Jeżeli powiesz: Pokaż mi twego Boga - odpowiem ci: Pokaż mi, że jesteś człowiekiem, a ja ci pokażę mego Boga. [...] Dusza ludzka powinna być tak czysta, jak zwierciadło odbijające światło. Gdy zaś do zwierciadła zakradnie się rdza, nie widać w nim ludzkiej twarzy. Tak też człowiek nie może widzieć Boga, gdy hołduje grzechom. Pokaż najpierw, kim jesteś, czy nie jesteś cudzołożnikiem, rozpustnikiem, złodziejem, rozbójnikiem, łupieżca, pederastą, oszczercą, przeklętnikiem, awanturnikiem, zazdrośnikiem, pyszałkiem, człowiekiem bez zasad, zabijaką, chciwcem, nieposłusznym wobec rodziców, handlarzem własnych dzieci. Tym, którzy takie rzeczy czynią, Bóg się nie objawia, dopóki się przedtem z wszelkiego brudu nie oczyszczą. Zatem wszystko to sprowadza na ciebie ciemności. Podobnie jak ropa uniemożliwia oczom oglądanie słońca, tak twoje bezbożności pogrążają cię w ciemnościach, byś nie mógł widzieć Boga ${ }^{7}$.

Bardzo podobnie św. Augustyn odpowiada na pytanie, co ma uczynić grzesznik, który pragnie poznać Boga:

Niech oczyści w sobie to, czym będzie mógł zobaczyć Boga. Kiedy ktoś ma kłopoty ze wzrokiem, gdyż oczy uległy skażeniu lub zostały zranione, zaszły prochem, ropa lub dymem, lekarz powie: Musisz oczyścić swoje oko, a oczy twoje odzyskają władzę widzenia. Otóż prochem, ropą, dymem są grzechy i niegodziwości. Wyrzuć z siebie to wszystko, a zobaczysz Mądrość, która stoi przed tobą. Albowiem Bóg jest ową Mądrością. Jak powiedziano: Błogosławieni czystego serca, albowiem oni Boga oglądać będą.

${ }^{5}$ H. Denzinger, A. Schönmetzer, Enchiridion symbolorum, definitionum et declarationum de rebus fidei et morum, Freiberg im Br. 1976, 3004.

${ }^{6}$ Tamże, 3005.

7 Święty Teofil z Antiochii, Do Autolyka, 1, 2, w: Apologeci greccy II wieku, thum. J. Czuj, Poznań 1935, s. 35 n.; tekst przekładu nieco poprawiony.

${ }^{8}$ Święty Augustyn, Wykład Ewangelii Jana, hom, 1, 19; PL 35, 1388. 
Najbardziej zdumiewa to, że niektórzy ludzie przywykli do swoich ciemności i obca im jest tesknota za światłem. „Światło przyszło na świat - wyjaśniał Pan Jezus Nikodemowi - lecz ludzie bardziej umiłowali ciemność aniżeli światło: bo złe były ich uczynki. Każdy bowiem, kto się dopuszcza nieprawości, nienawidzi światła i nie zbliża się do światła, aby nie potępiono jego uczynków" (J 3,19n).

Niektórzy nawet chlubią się swoimi ciemnościami i mają je za najprzedniejszą światłość. O takich Pan Jezus wypowiedział słowa, które mogą przerazić: „Jeśli światło, które jest w tobie, jest ciemnością, jakże wielka to ciemność!” (Mt $6,23)$.

Jeżeli ktoś zakochał się w swoich ciemnościach, może znaleźć się - żeby użyć metafory matematycznej - w ciemnościach do kwadratu: może doprowadzić do tego, że już nie tylko on ukrywa się przed Bogiem, ale że również Bóg zacznie ukrywać się przed nim. Przejmująco napisano o tym w Ewangelii Jana: „Chodźcie, dopóki macie światłość, aby was ciemność nie ogarnęła. A kto chodzi w ciemności, nie wie, dokąd idzie. Dopóki światłość macie, wierzcie w światłość, abyście byli synami światłości. To powiedział Jezus i odszedł, i ukrył się przed nimi" (J 12,35n).

Jeden tylko Bóg wie, dlaczego ukrywa się przed zakochanym w swoich ciemnościach grzesznikiem. Czy dlatego, żeby dopełniła się miara jego niegodziwości? Czy może dlatego, żeby uchronić go przed grzechem jeszcze większym? Fakt faktem, że agresja przeciw Bogu - choć sama w sobie absurdalna jest potrzebą niektórych grzeszników. Ponieważ Bóg bezpośrednio jest im niedostępny, prześladują Jego obecność w ludziach i wśród ludzi. Agresja ta osiaggnęła szczyt w Wielki Piątek. „To jest wasza godzina i panowanie ciemności” (Łk 22,53) - powiedział Pan Jezus, oddając się w ręce swoich zabójców.

\section{Światło wiary nie jest światłem przekonań ani światopoglądu}

W samym pojęciu „światło wiary” zawiera się konieczność jego zakorzenienia w autentycznym rozumieniu wiary. Jest czymś właściwie niewyobrażalnym, ażeby o świetle wiary dało się myśleć i mówić sensownie, gdybyśmy wiarę próbowali sprowadzić do posiadania religijnych przekonań albo do wyznawania religijnego światopoglądu - a więc do jednego z tych ujęć, które chciałaby nam narzucić mentalność dominująca w Europie od czasów oświecenia.

Gdyby wiara polegała tylko na posiadaniu religijnych przekonań, nie moglibyśmy wiedzieć, jak z Chrystusem jest naprawdę - ani czy naprawdę jest On Synem Bożym, ani czy nas odkupił, ani czy zmartwychwstał. Przede wszystkim zaś nie mielibyśmy żadnej możliwości wejścia $\mathrm{w}$ realne $\mathrm{z}$ Nim relacje. Czymś jeszcze mniejszym byłaby wiara zredukowana do wyznawania chrześcijańskiego 
światopoglądu, sprowadzona do subiektywnej odpowiedzi na pytanie o ostateczny sens świata i człowieka. Zupełnie nie widać, czym transcendentnym wobec nas miałyby świecić takie subiektywne przekonania czy poglądy.

Ojciec Święty Franciszek od razu w pierwszym numerze swej encykliki napisał, że światło wiary „przychodzi do nas od zmartwychwstałego Chrystusa”, a więc ze źródeł niewyobrażalnie głębszych niż nasze poglądy czy przekonania. „Światło wiary jest światłem Oblicza - napisze papież Franciszek wiele stron dalej - w którym widać Ojca. [...] Poznanie wiary nie zachęca nas do oglądania czysto wewnętrznej prawdy. Prawda, jaką przed nami odsłania wiara, jest prawdą skupioną na spotkaniu z Chrystusem, na kontemplacji Jego życia, na dostrzeganiu Jego obecności”".

Przypomnijmy tutaj niezwykle ważny wywód, zawarty w numerach 7-9 encykliki Spe salvi, w którym papież Benedykt XVI dopomina się o prawidłowe odczytanie definicji wiary, znajdującej się w Hbr 11,1. Od czasów bowiem Lutra przekłady tego wersetu - niestety, również w katolickich wydaniach Biblii poznańskiej oraz Biblii warszawsko-praskiej - fałszywie sugerują jakoby wiara polegała na posiadaniu przekonań.

Jedną z przyczyn tego, że termin ,światło wiary” we współczesnym kościelnym nauczaniu pojawia się raczej rzadko, wydaje się to, że nie dość jasno odróżniamy dzisiaj wiarę od przekonań i światopoglądu. Tym więcej powinniśmy być wdzięczni Ojcu Świętemu, że wykład na temat światła wiary uczynił ważnym wątkiem, a w gruncie rzeczy głównym tematem swej encykliki.

Poniekąd sercem tej encykliki jest jej numer 4. Papież przedstawia tam wiarę, której światło przychodzi do nas od zmartwychwstałego Chrystusa, a zarazem z transcendentnej wobec naszego czasu przyszłości. Ma ono moc rozświetlać całe nasze życie, „kierować spojrzenie w przyszłość” i przeprowadzić nas poza granice śmierci. Światło tak potężne - powiada papież Franciszek - nie może pochodzić od nas samych.

Dodajmy jeszcze niezwykle ważną uwagę papieża Franciszka, że światło wiary rozjaśnia nie tylko całe nasze życie, ale wręcz nas samych - a od tego, do jakiego stopnia na to światło się otwieramy, istotnie zależy rozszerzanie się ewangelicznego orędzia.

Światło Jezusa - że zacytuję nr 40 encykliki - jaśnieje jak w zwierciadle na obliczach chrześcijan i tak się rozchodzi, i tak dociera do nas, abyśmy i my mieli udział w tym widzeniu i odzwierciedlali innym Jego światło, tak jak światło paschału, które w liturgii wielkanocnej zapala tyle innych świec. Wiara przekazywana jest, można powiedzieć, od osoby do osoby, podobnie jak płomień zapala się od innego płomienia ${ }^{10}$.

\footnotetext{
${ }^{9}$ Franciszek, Lumen fidei, Kraków 2013, nr 30.

${ }^{10}$ Franciszek, Lumen fidei, dz. cyt., 40.
} 


\section{Trzy spostrzeżenia szczegółowe}

Na koniec tej części artykułu przedstawię trzy ważne spostrzeżenia Akwinaty, z których pierwsze dotyczy relacji między światłem wiary a światłem rozumu:

Dary łaski są w ten sposób udzielane naturze, że jej samej nie niszczą, ale raczej doskonala. Dlatego i światło wiary, które jest nam dawane jako dar, nie niszczy światła rozumu naturalnego, również danego nam przez Boga. I choć światło naturalne ludzkiego umysłu jest niewystarczające do ujawnienia tego, co ujawniane jest przez wiarę, to jednak jest niemożliwe, aby to, co jest nam przekazywane od Boga przez wiarę, było przeciwne temu, co dawane jest przez naturę. Wtedy jedno z nich musiałoby być fałszywe. A skoro obydwa mamy od Boga, Bóg byłby w nas sprawcą fałszu, co jest niemożliwe ${ }^{11}$.

Tezę powyższą powtórzył Sobór Watykański I, w Konstytucji dogmatycznej o wierze katolickiej, cap. 4, oraz Jan Paweł II, w encyklice Fides et ratio, 34. Tomasz nie zapomni dodać, że poznanie w świetle wiary jest zdecydowanie doskonalsze niż poznanie w świetle jedynie naturalnego rozumu:

Ponieważ w rzeczach niedoskonałych znajduje się pewne naśladownictwo rzeczy doskonałych, dlatego w tym, co jest poznawane dzięki rozumowi naturalnemu, znajdują się pewne podobieństwa do tego, co przekazywane jest dzięki wierze. Jak zaś święta nauka opiera się na świetle wiary, tak filozofia opiera się na świetle naturalnego rozumu. Stąd niemożliwe jest, aby twierdzenia filozofii były przeciwne twierdzeniom wiary, ale te pierwsze nie dorównują doskonałości drugich ${ }^{12}$.

Po wtóre: światło wiary - twierdzi św. Tomasz - nie we wszystkich wierzących jest jednakowo silne. „Światło Boże przyjmujemy stosownie do swojej pojemności. Otóż wiarę sprawia w nas działanie światła Bożego, zatem trzeba, ażeby światło to było przez nas przyjmowane stosownie do naszej pojemności"13.

Po trzecie: światło wiary niekiedy jest $\mathrm{w}$ nas zaciemnione przez grzech. Swoją doskonałość akt wiary czerpie zarówno z umysłu, jak z woli. A przecież wiara nieukształtowana przez miłość, tzn. kiedy wierzący pozbawiony jest łaski uświęcającej, nie jest zdolna do aktu doskonałego ${ }^{14}$.

${ }^{11}$ Sancti Thomae de Aquino, In Böethium de Trinitate, lib.1 a. 3; przekład polski: Święty Tomasz z Akwinu, O poznaniu Boga, tłum. Mateusz Przanowski, Kraków 2005, s. 129.

${ }^{12}$ Tamże.

13 „Lumen divinum non recipitur in nobis nisi secundum nostram proportionem; fides autem causatur in nobis ex influentia divini luminis; et ideo oportet quod istud divinum lumen secundum nostram proportionem in nobis recipiatur" - Sancti Thomae de Aquino, 3 Sent. d.21 q.2 a.3.

${ }^{14}$ „Quia ergo credere est actus intellectus, secundum quod est motus a voluntate; ad hoc quod iste actus perfectus sit, oportet quod intellectus perfectus sit per lumen fidei, et voluntas sit perfecta per habitum caritatis; et ideo informis fides non habet actum perfectum, et ideo non potest esse virtus" - Sancti Thomae de Aquino, 3 Sent. d.23 q.3 a.1 q-la 2. 


\section{Światlo chwały}

Rzecz jasna, wyraz „światło” ma tu znaczenie całkowicie metaforyczne.

Ponieważ [...] do poznania rzeczy umysłowych dochodzimy przez poznanie rzeczy zmysłowych, na poznanie umysłowe przenosimy również nazwy z poznania zmysłowego, zwłaszcza te odnoszące się do wzroku, który wśród wszystkich zmysłów jest najszlachetniejszy i najbardziej uduchowiony, i przez to najbliższy intelektowi. Stąd też i poznanie intelektualne nosi nazwę widzenia. A ponieważ widzenie cielesne dokonuje się za pomocą światła, to, dzięki czemu realizuje się widzenie intelektualne, również nazywa się światłem. Dlatego [...] owo usprawnienie, które wynosi intelekt stworzony do intelektualnego widzenia substancji Bożej, słusznie nazywa się świathem chwały ${ }^{15}$.

Źródłem pojęcia „światło chwały” są zwłaszcza dwie zapowiedzi biblijne: „W Twojej światłości zobaczymy światłość” (Ps 36,10) oraz „Umiłowani, obecnie jesteśmy dziećmi Bożymi, ale jeszcze się nie ujawniło, czym będziemy; wiemy, że gdy się objawi, będziemy do Niego podobni, bo ujrzymy Go takim, jakim jest” (1 J 3,2) - a ponadto opisy życia wiecznego w Apokalipsie: „Miastu nie trzeba słońca ni księżyca, by mu świeciły, bo chwała Boga je oświetliła, a jego lampą - Baranek” (Ap 21,23) oraz „Odtąd już nocy nie będzie. A nie potrzeba im światła lampy i światła słońca, bo Pan Bóg będzie świecił nad nimi i będą królować na wieki wieków" (Ap 22,5).

W Wykładzie Księgi Izajasza Akwinata napisał, że podobnie jak światło rozumu uzdalnia nas do naturalnej kontemplacji rzeczywistości niewidzialnych, podobnie jak światło wiary podnosi do kontemplacji nadprzyrodzonej umysły pielgrzymujących do życia wiecznego - tak światło chwały uzdalnia błogosławionych w niebie do oglądania Boga w Jego istocie, a ta kontemplacja w pełni i doskonale możliwa jest tylko w Ojczyźnie ${ }^{16}$.

Światło chwały - dar absolutnie przekraczający naturalne możliwości najdoskonalszych nawet stworzeń - czyni stworzenie rozumne bogokształtnym ${ }^{17}$. Światło to jest nieutracalne, „ponieważ to światło jest przyjmowane w sposób niezniszczalny, zgodnie z naturą i przyjmującego, i dającego"18. „Jest [ono] pewną podobizną intelektu Bożego", zarazem może ono jednych upodabniać do Boga więcej niż innych ${ }^{19}$.

${ }^{15}$ Św. Tomasz z Akwinu, Summa contra Gentiles. Prawda wiary chrześcijańskiej, lib.3 cap.53 n.5, tłum. Z. Włodek, W. Zega, Poznań 2007, t. 2, s. 153.

${ }^{16}$ Sancti Thomae de Aquino, Super Isaiam, cap. 11,1.

17 "Per hoc lumen fit creatura rationalis deiformis" - Sancti Thomae de Aquino, STh 1 q.12 a.5 ad 3.

${ }^{18}$ Sancti Thomae de Aquino, Summa contra Gentiles, lib. 3 cap.62 n.5 (przekład polski: t. 2, s. 172).

${ }^{19}$ Sancti Thomae de Aquino, Summa contra Gentiles, lib. 3 cap.58 n.3 (przekład polski: t. 2, s. 164). 
Rzecz jasna, „dzięki światłu chwały intelekt stworzony nigdy nie wzniesie się tak, by nie był oddalony nieskończenie od istoty Boga", jednak przecież „dzięki owemu świattu dokonuje się to, że intelekt łączy się z istotą Boga jako formą intelektualnie poznawalną, co w inny sposób stać by się nie mogło"20.

\section{Zamiast podsumowania}

Dwa poczynione wyżej ustalenia wydają mi się szczególnie ważne. Po pierwsze: pojęcie „światło wiary” jest czymś więcej niż przypadkową metaforą - zawiera ono ściśle określone miejsce $\mathrm{w}$ szeregu trzech zhierarchizowanych metafor, które przedstawiają trzy zdecydowanie odmienne sytuacje naszego dostępu do prawdy.

Po wtóre: światło wiary płynie ze źródeł niewyobrażalnie głębszych niż nasze poglądy czy przekonania, bo - jak to niezwykle trafnie sformułował w swojej encyklice papież Franciszek - ,przychodzi ono do nas od zmartwychwstałego Chrystusa".

\section{The Question of "The Light of Faith" in the Perspective of the Thought of Thomas Aquinas}

\section{Summary}

It seems that one of the reasons why the term "the light of Faith" occurs rarely in modern Church teaching is that today we do not distinguish clearly enough faith from convictions and worldview. In terms of St. Thomas Aquinas the concept of "the light of Faith" is something more than an accidental metaphor. It occupies a precise position in a series of three hierarchical metaphors that represent three radically different situations of our access to the truth. The article explains what in the texts of Aquinas is the light of reason, the light of Faith and the light of glory.

\section{Keywords}

the light of reason, the light of Faith, the light of glory

\section{Stowa kluczowe}

światło rozumu, światło wiary, światło chwały

${ }^{20}$ Św. Tomasz z Akwinu, Kwestie dyskutowane o prawdzie, q.8 a.3 ad 14, thum. Leszek Kuczyński, Kęty 1998, t. 1, s. 335. 